\title{
Optimalisasi Peran BUM Desa dalam Pengembangan Ekonomi Perdesaan di Masa Pandemi Covid-19^
}

\author{
Rizki Zakariya ${ }^{\mathrm{a}, *}$ \\ ${ }^{a}$ Fakultas Hukum Sekolah Tinggi Hukum Indonesia Jentera
}

\begin{abstract}
The Covid-19 pandemic is hurting the socio-economic activities of the community in rural areas. The purpose of this study is to describe the urgency of optimizing the role of village-owned enterprises (BUM Desa) in developing rural economies amid the Covid-19 Pandemic and the optimization strategy. The research method used is descriptive qualitative with a case approach and a statutory approach. The pandemic has hit rural communities hard. The efforts to optimize the role of BUM Desa include encouraging them to provide staple foods in the villages, cooperating with various external parties, providing incentives and working capital, and providing education and training for their managers.
\end{abstract}

Keywords: rural areas; BUM Desa; economic development; Covid-19 pandemic

\begin{abstract}
Abstrak
Pandemi Covid-19 berdampak negatif pada aktivitas sosial-ekonomi masyarakat perdesaan. Penelitian ini bertujuan menguraikan urgensi dan strategi optimalisasi peran Badan Usaha Milik Desa (BUM Desa) dalam mengembangkan ekonomi perdesaan di tengah pandemi. Metode penelitian yang digunakan, yaitu deskriptif kualitatif dengan pendekatan kasus dan tinjauan regulasi. Hasil penelitian menunjukkan urgensi BUM Desa karena kontribusinya yang besar bagi desa, tetapi terdisrupsi oleh pandemi. Upaya optimalisasi peran BUM Desa di antaranya dengan mendorong BUM Desa sebagai penyedia bahan makanan pokok di desa, bekerjasama dengan berbagai pihak eksternal, pemberian insentif dan kredit modal kerja, dan dilakukannya pendidikan dan pelatihan SDM pengelola.
\end{abstract}

Kata Kunci: ekonomi perdesaan; BUM Desa; pembangunan ekonomi; pandemi Covid-19 Kode Klasifikasi JEL: O17; O35; P25; R11;, R23

${ }^{\star}$ Penulis mengucapkan terima kasih kepada Allah SWT, Tuhan semesta alam. Karena atas limpahan berkahnya saya dapat menyelesaikan paper ini. Kemudian kepada berbagai pihak yang terlibat dalam penelitian ini. Semoga pada penelitian selanjutnya masalah kekurangan dalam penelitian ini dapat diperbaiki lebih baik.

${ }^{*}$ Alamat Korespondensi Penulis: Jl. Kuningan Madya Kav. 5-6, Kel. Guntur, Kec. Setiabudi, Kota Jakarta Selatan, DKI Jakarta 12980. E-mail: rizkizakariya5@gmail.com. 


\section{Pendahuluan}

Sejarah mencatat, desa merupakan cikal bakal terbentuknya masyarakat politik dan pemerintahan jauh sebelum adanya negara Indonesia terbentuk (Jamaludin, 2015). Di Indonesia, saat ini terdapat 75.436 desa (BPS, 2018). Desa-desa tersebut berkontribusi terhadap perekonomian melalui penyerapan tenaga kerja serta pemenuhan kebutuhan pokok nasional. Dalam bidang perekonomian, desa menyumbang bagi penerimaan Produk Domestik Bruto (PDB) dan pajak nasional (liputan6.com, 2019). Desa juga menyerap tenaga kerja dalam jumlah besar, khususnya pada pertanian yang mencapai 39,7 juta orang atau 32\% tenaga kerja nasional pada 2017 (Koran Jakarta, 2017). Pertanian di desa pun berkontribusi bagi penyediaan kebutuhan pokok nasional melalui Badan Urusan Logistik (Bulog) (beritasatu.com, 2020a). Hal itu tidak terlepas dari kegiatan utama di desa dimana 57\% masyarakat desa pada 2012 bekerja di sektor pertanian (Ditjen PKP). Dengan berbagai kontribusi itu, desa harus memperoleh perhatian dan dukungan untuk pengembangan ekonominya.

Namun, Covid-19 telah berdampak pada kondisi perekonomian desa. Hal tersebut dikarenakan sekitar 70,53\% pekerja di sektor informal, termasuk pertanian, mengalami penurunan pendapatan (BPS, 2020a,b). Lebih lanjut, Covid-19 menyebabkan produktivitas tenaga kerja dan hasil produksi pertanian menurun, dan meningkatkan biaya perdagangan (Basit, 2020). Selain itu, Covid-19 juga berdampak terhadap kesehatan masyarakat pedesaan karena sebagian besar orang dalam pengawasan (ODP) paling banyak berasal dari pedesaan (tribunnews.com, 2020). Kondisi tersebut terjadi karena pertanian merupakan pekerjaan yang perlu dilakukan secara berkelompok (Elizabeth, 2007) dan kondisi tersebut merupakan salah satu jalur penularan Covid-19 (Nuryanti \& Swastika, 2011). Kerentanan penularan Covid-19 tersebut terlebih karena kondisi masyarakat desa yang sebesar 31,1\% berusia di atas 40 tahun, yang rentan tertular Covid-19 dengan tingkat kematian 10-14\% (Kompas.com, 2020a). Oleh karena itu, Pemerintah berupaya mencegah penularan Covid-19 di desa, dengan menetapkan Pembatasan Sosial Berskala Besar (PSBB) mengikuti Pemerintah Daerah (Kab/Kota) setempat. Di sisi lain, PSBB menghambat aktivitas masyarakat desa, termasuk bagi pekerja di sektor pertanian. Akibatnya, mata pencarian masyarakat desa menghilang. Padahal, pendapatan dari pekerjaan ini merupakan sumber utama untuk memenuhi kebutuhan pokok sehari-hari (Abdulgani et al., 2020). Lebih lanjut, Covid-19 juga berdampak pada penurunan harga jual hasil pertanian masyarakat desa, sehingga menimbulkan kerugian ekonomi. Oleh karena itu, Pemerintah harus hadir untuk mencegah dampak ekonomi yang lebih buruk di desa. Upaya tersebut salah satunya dengan mengoptimalkan peran Badan Usaha Milik Desa (BUM Desa) dalam memulihkan dan mengembangkan ekonomi desa yang terdampak Covid-19. Hal tersebut merupakan latar belakang penulisan ini.

Berdasarkan latar belakang tersebut, maka tujuan penelitian ini terdiri atas dua hal. Pertama, menguraikan dan menjelaskan urgensi optimalisasi peran BUM Desa dalam pengembangan ekonomi perdesaan di tengah pandemi Covid- 
19. Kedua, menguraikan dan menganalisis upaya optimalisasi peran BUM Desa dalam pengembangan ekonomi perdesaan di tengah Pandemi Covid-19.

Penelitian ini membahas mengenai upaya optimalisasi peran BUM Desa, namun dengan analisis kondisi waktu yang berbeda, yakni pada masa Pandemi Covid-19. Penelitian mengenai optimalisasi peran BUM Desa telah dilakukan oleh peneliti sebelumnya, di antaranya oleh Puspayanthi et al. (2017) yang meneliti di Kabupaten Jembrana, Bali. Menurutnya, optimalisasi BUM Desa dapat dilakukan dengan mengoptimalkan pengelolaan keuangan dan pemilihan jenis usaha BUM Desa berdasarkan potensi lokal desa. Kemudian, menurut Wibisono \& Panuntun (2020), optimalisasi peran BUM Desa dapat dilakukan dengan penguatan pendampingan BUM Desa baik untuk menata organisasi maupun cara menjalankan bisnisnya secara berkelanjutan (Wibisono \& Panuntun, 2020). Selanjutnya, dalam penelitian Filya (2018) di Bojonegoro disebutkan bahwa optimalisasi dengan peningkatan kompetensi sumber daya manusia BUM Desa, baik dengan persyaratan keahlian tertentu saat rekrutmen atau dengan pelatihan. Sama dengan Afifa tersebut. Adapun menurut Juliman \& Muslimin (2019), optimalisasi BUM Desa dilakukan dengan meningkatkan kompetensi sumber daya pengelola BUM Desa dan peran aktif pemerintah desa dalam menerima laporan rutin, evaluasi kinerja, serta rencana kerja BUM Desa. Berbagai hasil penelitian tersebut menjadi pedoman penulis dalam melakukan penelitian ini. Akan tetapi, perbedaan penelitian sebelumnya pada penelitian ini terletak pada fokus optimalisasi di masa Covid-19 yang sedang terjadi di desa saat ini.

\section{Metode}

\subsection{Jenis Penelitian}

Metode penelitian yang digunakan dalam penelitian ini ialah penelititian deskriptif kualitatif dengan pendekatan kasus (case approach), dan pendekatan undangundang (statute approach). Pendekatan tersebut digunakan supaya pembahasan sesuai dengan fokus ruang lingkup yang dituju. Menurut Marzuki (2011), pendekatan kasus adalah pendekatan yang dilakukan dengan cara melakukan telaah terhadap kasus-kasus yang berkaitan dengan isu yang dihadapi terkait hukum. Sedangkan, pendekatan undang-undang dilakukan dengan menelaah semua undang-undang atau regulasi yang terkait dengan penelitian (Ibrahim, 2007). Penelitian deskriptif kualitatif adalah suatu metode dalam meneliti status sekelompok manusia, suatu objek dengan tujuan memuat deskripsi, gambaran, atau lukisan secara sistematis, faktual, dan akurat, mengenai fakta atau fenomena yang sedang diselidiki (Sevilla et al., 1993).

\subsection{Jenis dan Sumber Data}

Dalam menjawab permasalahan penelitian, maka digunakan 3 (tiga) sumber data yang diperoleh melalui penelitian kepustakaan (library research). Ketiga bahan hukum sebagai sumber data tersebut di antaranya: 
1. Bahan Hukum Primer

2. Bahan Hukum Sekunder

Bahan hukum sekunder yang digunakan dalam penelitian ini terdiri dari bukti, temuan, atau laporan historis yang dipublikasikan maupun tidak dipublikasikan. Bahan hukum ini meliputi pendapat hukum/doktrin/teori yang diperoleh dari buku, laporan penelitian, jurnal, karya ilmiah, laporan tahunan, dan artikel pada berbagai majalah, website, dan jurnal ilmiah.

3. Bahan Hukum Tersier

Bahan hukum tersier yang digunakan dalam penelitian ini adalah Kamus Besar Bahasa Indonesia, indeks kumulatif, dan sebagainya yang berkaitan dengan obyek penelitian, serta sumber lain yang menopang penelitian penulis.

\subsection{Teknik Pengumpulan Data}

Untuk memperoleh berbagai data terkait penelitian, penulis menggunakan empat tahapan. Pertama, editing, yakni pemeriksaan ulang bahan hukum mulai dari kelengkapan, kejelasan makna, kesesuaian, dan relevansi dengan isu terkait penelitian. Kedua adalah coding, yakni pemberian catatan yang menyatakan jenis sumber bahan hukum (buku, jurnal, undang-undang, penelitian, dan sebagainya); dan pemegang hak cipta (nama penulis dan tahun terbit). Selanjutnya ketiga, merekonstruksi, yakni menyusun ulang baha-bahan sumber penelitian secara teratur, urut, dan logis. Sehingga mudah untuk dipahami dan interpretasikan. Selanjutnya keempat, sistematisasi bahan hukum, yakni menempatkan bahan hukum secara berurutan berdasar kerangka sistematika pembahasan yang mengacu pada urutan masalah.

\section{Hasil dan Pembahasan}

\subsection{Urgensi Optimalisasi Pengembangan Ekonomi Perdesaan di Tengah Pandemi Covid-19}

\subsubsection{Potensi Ekonomi Pedesaan}

Desa merupakan elemen terkecil dari negara, namun terdekat dengan masyarakat. Pasal 1 angka (1) Undang-Undang No. 6 Tahun 2014 tentang Desa (selanjutnya disebut dengan UU Desa) menyatakan bahwa desa adalah kesatuan masyarakat hukum yang memiliki batas wilayah yang berwenang untuk mengatur dan mengurus urusan pemerintahan, kepentingan masyarakat setempat berdasarkan prakarsa masyarakat, hak asal usul, dan/atau hak tradisional yang diakui dan dihormati dalam sistem pemerintahan Negara Kesatuan Republik Indonesia. Melalui pasal tersebut, maka desa memiliki hak rekognisi dan subsidiaritas untuk penguatan desa yang mandiri. Rekognisi merupakan pengakuan terhadap asal-usul, sedangkan subsidiaritas adalah penetapan kewenangan berskala lokal dan pengambilan keputusan secara lokal untuk kepentingan masyarakat desa 
(Laksono et al., 2016). Penguatan kewenangan desa dalam UU Desa tersebut dilakukan karena desa memberikan banyak kontribusi bagi perekonomian lokal dan nasional.

Hasil pendataan potensi desa (Podes) tahun 2018 oleh Badan Pusat Statistik (BPS) menunjukkan bahwa Indonesia memiliki 83.931 wilayah administrasi pemerintahan setingkat desa yang terdiri dari 75.436 desa, 8.444 kelurahan, dan 51 UPT/SPT (BPS, 2018). Keberadaan desa-desa tersebut memberikan kontribusi bagi perekonomian nasional, penyerapan tenaga kerja, dan pemenuhan kebutuhan pokok nasional. Dalam hal ekonomi, desa memiliki banyak kegiatan usaha, mulai dari usaha mikro kecil dan menengah yang mencapai 146.876, koperasi mencapai 33.886, dan unit usaha perdagangan serta akomodasi mencapai 219.413 (BPS, 2019). Dengan berbagai kegiatan usaha tersebut, maka desa memberikan kontribusi pada penerimaan pajak dan PDB nasional, maupun daerah. Lebih lanjut, desa yang memiliki karakteristik pekerjaan di sektor pertanian, mampu menyerap tenaga kerja di sektor itu dalam jumlah besar, yakni sebanyak 39,7 juta orang atau 32\% tenaga kerja nasional pada tahin 2017. Selanjutnya, desa juga berkontribusi sebagai pemasok kebutuhan pokok nasional, seperti padi yang mencapai 81.148.594 ton pada 2017 (Kementerian Pertanian, 2018) yang kemudian diolah menjadi beras oleh Badan Urusan Logistik (Bulog). Produksi padi setiap tahun oleh petani di desa terus mengalami peningkatan, hal itu dapat dilihat pada grafik berikut:

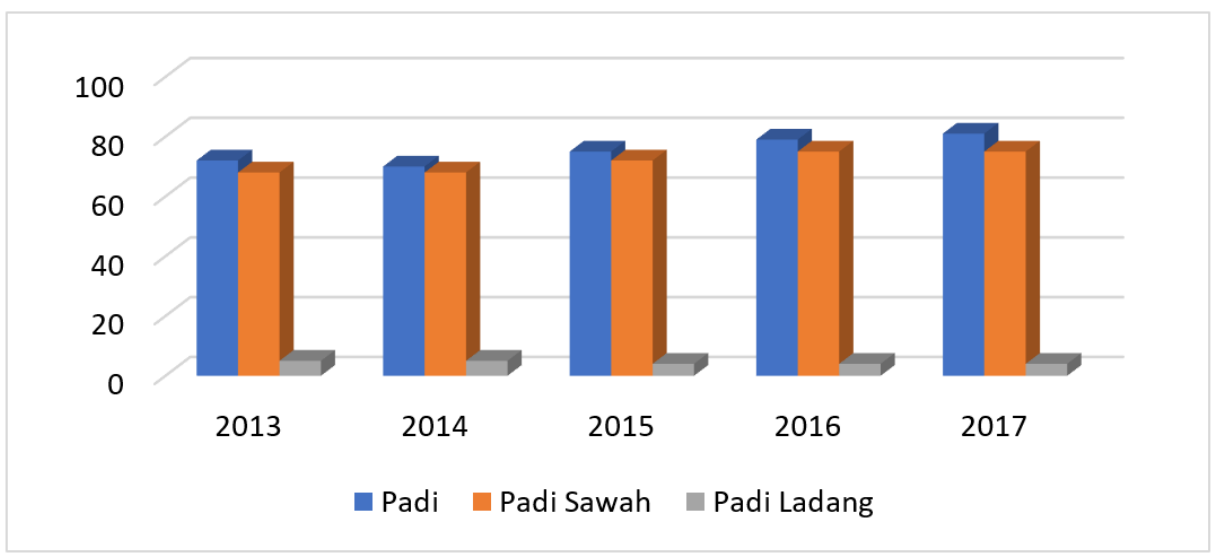

Gambar 1: Peningkatan Produksi Padi Pertanian di Desa 2013-2017

\subsubsection{Dampak Ekonomi di Desa Akibat Covid-19}

Berdasarkan uraian sebelumnya tersebut, maka jelas desa memberikan kontribusi bagi perekonomian nasional. Akan tetapi, pandemi Covid-19 di Indonesia sejak 2 Maret 2020, menimbulkan dampak negatif bagi ekonomi di desa. Dam- 
pak negatif tersebut setidaknya dilihat pada 5 (lima) hal. Pertama, penurunan harga dan kesulitan penjualan hasil panen pertanian. BPS mencatat penurunan harga gabah kering petani mencapai 6,82\% pada April 2020 dibanding periode bulan sebelumnya, dan terus mengalami penurunan. Sedangkan, berdasarkan temuan lapangan, selama Covid-19 penurunan harga gabah mencapai 50\% dari kondisi normal seperti yang dialami para petani di Kecamatan Sutera, Kabupaten Pesisir Selatan, Sumatera Barat. Bahkan, bukan hanya penurunan harga, Covid-19 juga menyebabkan hasil pertanian seperti bawang tidak laku di pasar, seperti yang dialami oleh Kelompok Tani Sudi Makaryo di Temanggung, Jawa Tengah. Perlu diketahui, bahwa sejak dikeluarkannya penetapan status darurat Covid-19 melalui Keputusan Presiden Nomor 11 Tahun 2020 Tentang Penetapan Kedaruratan Kesehatan Masyarakat Corona Virus Disease 2019 dan Peraturan Menteri Kesehatan Nomor 9 Tahun 2020 Tentang Pedoman Pembatasan Sosial Berskala Besar, maka aktivitas kehidupan sehari-hari masyarakat mengalami pembatasan, tidak terkecuali kegiatan ekonomi. Berdasarkan data Laporan Tim Gugus Tugas Percepatan Penanganan Covid-19, sampai 22 Mei 2020 terdapat 4 Provinsi, dan 22 Kabupaten/Kota yang menerapkan PSBB di wilayahnya masingmasing. Sehingga dengan pembatasan tersebut, menyebabkan kerugian ekonomi masyarakat.

Selanjutnya dampak negatif Covid-19 bagi perekonomian di pedesaan yang kedua, yakni kerentanan penularan Covid-19 pada buruh pertanian di desa. Hal itu karena pertanian merupakan bidang pekerjaan yang perlu dilakukan secara berkelompok (Nuryanti \& Swastika, 2011), di mana kondisi tersebut merupakan salah satu jalur penularan Covid-19 (Kompas.com, 2020a). Kerentanan penularan Covid-19 tersebut terlebih karena kondisi masyarakat desa yang sekitar 31,1\% berusia di atas 40 tahun, yang rentan tertular Covid-19 dengan tingkat kematian 10-14\% (Perhimpunan Dokter Paru Indonesia [PDPI], 2020). Kemudian penularan Covid-19 di desa juga disebabkan karena banyaknya pekerja dari desa yang pulang ke kampung halamannya selama Covid-19, yang berpotensi menularkannya ke masyarakat desa. Berdasarkan temuan Pemerintah Daerah Provinsi Jawa Barat, seiring lonjakan arus mudik dari Jakarta ke kota-kota di Jawa Barat, jumlah Orang Dalam Pemantauan (ODP) meningkat sampai 5 kali lipat dari bulan sebelumnya yang mencapai 12.453 orang. Lonjakan itu juga terjadi pada orang yang positif Covid-19, yang naik 3 kali lipat dari bulan sebelumnya atau 2.405 orang orang (voaindonesia.com, 2020).

Ketiga, yakni rantai pasok hasil pertanian dari desa yang melambat dan berkurang. Penerapan PSBB pada sejumlah daerah menyebabkan angkutan hasil pertanian sulit memasuki daerah tujuan. Hal itu seperti yang dikeluhkan oleh Pemerintah Daerah Kabupaten Cianjur karena truk pengangkut beras Cianjur tidak bisa masuk ke daerah lain selama Covid-19, karena adanya pembatasan keluar-masuk kendaraan di berbagai daerah (Hidayat, 2020). Peristiwa serupa juga dialami oleh pembeli (tengkulak) hasil panen jagung di Lamongan, Jawa Timur, yang tidak bisa membeli jagung dari desa-desa, karena adanya pembatasan orang masuk wilayah desa tersebut (Hidayat, 2020). Kedua peristiwa tersebut 
merupakan bentuk rantai pasok pertanian yang melambat dan berkurang akibat adanya Covid-19.

Selanjutnya dampak keempat, yakni meningkatnya angka pengangguran di pedesaan, terlebih lagi akibat dari arus balik pengangguran kota ke desa. Data Badan Pusat Statistik dan Bappenas menyebutkan Covid-19 berimplikasi pada meningkatnya angka pengangguran akibat pemutusan hubungan kerja (PHK), yang mencapai 10,58 juta pekerja (Hidayat, 2020). Kemudian menurut Johan Rosihan, 62,6\% atau 5 juta pekerja di antaranya adalah masyarakat yang bekerja pada sektor pertanian di desa (Media Indonesia, 2020) sehingga Covid-19 berdampak juga pada meningkatnya angka pengangguran di desa.

Kelima, menurunnya daya beli masyarakat pedesaan, dimana menurut Menteri PPN/Bappenas, Suharso Monoarfa, daya beli masyarakat menurun sebesar Rp362 triliun selama 30 Maret 2020 hingga 6 Juni 2020 akibat Covid-19 (antaranews.com, 2020). Penurunan daya beli tersebut disebabkan menurunnya pendapatan masyarakat selama masa pandemi Covid-19 karena aktivitas ekonomi yang dibatasi (Kompas.com, 2020b). Hal itu sebagaimana temuan Center for Strategic and International Studies (CSIS) dan Presiden Joko Widodo yang menyatakan deflasi selama Covid-19 mencapai 0,13\% (beritasatu.com, 2020b). Kelima hal tersebut merupakan dampak Covid-19 pada perekonomian masyarakat di desa, sehingga banyak merugikan masyarakat desa.

\subsubsection{Potensi Badan Usaha Milik Desa (BUM Desa)}

Sejak awal, desa telah diarahkan untuk bisa mengelola dan menjalankan badan usaha sendiri. Hal itu sebagaimana termuat dalam Penjelasan Pasal 21 UndangUndang No. 5 Tahun 1979 tentang Pemerintahan Desa. Kemudian dalam UndangUndang No. 22 Tahun 1999 tentang Pemerintahan Daerah Jo. Undang-Undang No. 32 Tahun 2004 Jo. Undang-Undang No. 6 Tahun 2014 tentang Desa juga menyatakan bahwa desa dapat mendirikan badan usaha. Aturan turunan mengenai BUM Desa dari undang-undang tersebut di antaranya Peraturan Menteri Dalam Negeri (Permendagri) Nomor 39 Tahun 2010 tentang Badan Usaha Milik Desa. Dengan dasar hukum tersebut, maka upaya penggerakan ekonomi desa melalui BUM Desa dapat terlaksana secara optimal. Keberadaan BUM Desa berbeda dengan unit usaha lain yang ada di desa. Adapun perbedaan BUM Desa dengan unit usaha lain terletak pada tujuh karakteristik yang membedakannya, sebagai berikut (Junaidi, 2018):

1. Badan usaha ini dimiliki oleh desa dan dikelola bersama oleh masyarakat desa.

2. Modal usaha bersumber dari desa (51\%) dan dari masyarakat (49\%) melalui penyertaan modal (saham atau andil).

3. Usaha dijalankan dengan falsafah bisnis yang berasal dari budaya lokal (lokal wisdom).

4. Bidang usaha BUM Desa berdasarkan potensi dan hasil informasi pasar.

5. Hasil keuntungan digunakan untuk meningkatkan kesejahteraan anggota (penyerta modal) dan masyarakat desa umumnya berdasarkan kebijakan 
desa.

6. Adanya fasilitasi dari Pemerintah Pusat, Provinsi, Kabupaten, dan Desa.

7. Adanya kontrol usaha dari Pemerintah Desa, BPD, dan penyerta modal.

Atas perbedaan BUM Desa dengan unit usaha lain tersebut, maka BUM Desa memiliki tiga tujuan yang hendak dicapai dengan keberadaannya. Tujuan tersebut di antaranya mengoptimalkan pengelolaan aset-aset desa, memajukan perekonomian desa, serta meningkatkan kesejahteraan masyarakat desa (Dewi, 2014). Pemajuan perekonomian masyarakat desa dilakukan BUM Desa karena masih tingginya angka kemiskinan di desa. Per Maret 2017, kemiskinan di desa mencapai 13,93\% atau 17 juta orang, dan pada Maret 2018 mencapai 13,2\% atau 15,71 juta orang (Izzati, 2018). Tingginya kemiskinan di desa menunjukkan perlunya upaya bersama meningkatkan perekonomian dan pendapatan masyarakat desa. Keberadaan unit-unit BUM Desa merupakan amanat UU Desa yang selama ini belum berjalan secara optimal untuk mengurangi angka kemiskinan di desa. Hal itu berdasarkan temuan penelitian Pusat Telaah dan Informasi Regional di 4 (empat) BUM Desa di tiga kabupaten, yakni Kabupaten Kebumen, Kabupaten Siak, dan Kabupaten Bantul. Hasil penelitian itu menunjukan bahwa BUM Desa belum menjalankan fungsinya secara optimal karena empat hal, di antaranya: 1) rendahnya inisiatif internal desa dalam menggerakan ekonomi desa melalui BUM Desa; 2) ketidakjelasan posisi BUM Desa sebagai institusi sosial dan komersial di desa dalam UU Desa; 3) kebijakan dalam Permendesa No. 4 Tahun 2014 tentang BUM Desa yang belum mengarahkan profesionalisme pengelolaan BUM Desa, baik dalam menjalankan tugas maupun pengawasannya; dan 4) kurangnya pembinaan dan pendampingan berkelanjutan ke BUM Desa. Empat hal tersebut merupakan masalah yang harus dibenahi dalam pengoptimalan fungsi BUM Desa untuk mewujudkan kesejahteraan masyarakat desa.

Optimalisasi peran BUM Desa tersebut harus dilakukan terlebih pada masa Covid-19 saat ini, yang banyak merugikan ekonomi masyarakat desa. Hal itu dilakukan karena BUM Desa memiliki lima peran sentral dalam perekonomian desa yang terkait dengan bidang berikut:

1. Terkait Produksi (Budidaya/Pengolahan)

Pasal 22 ayat (1) Peraturan Menteri Desa, Pembangunan Daerah Tertinggal, Dan Transmigrasi Nomor 4 Tahun 2015 Tentang Pendirian, Pengurusan Dan Pengelolaan, Dan Pembubaran Badan Usaha Milik Desa (disebut Permendesa 4/2015) menyatakan bahwa BUM Desa dapat menjalankan usaha produksi/dagang barang sesuai kebutuhan masyarakat maupun pemasaran dalam jumlah besar. Jenis usaha tersebut seperti pabrik es, pabrik asap cair, hasil pertanian, sarana produksi pertanian, sumur bekas tambang, dan kegiatan bisnis produktif lainnya. Salah satu BUM Desa yang sukses dalam budidaya adalah BUM Desa Makmur Rejo, Desa Bandungrejo, Kecamatan Ngasem, Kabupaten Bojonegoro, Jawa Timur. BUM Desa tersebut sukses membudidayakan ayam petelur, dengan omset harian mencapai Rp3,2 juta (suarabanyuurip.com, 2020). Dengan langkah tersebut, maka BUM Desa mampu menggerakan ekonomi dan menyerap banyak tenaga kerja di desa. 
2. Terkait perdagangan/jasa

Selain produksi, BUM Desa juga dapat mengorganisir hasil produksi dan jasa yang dijalankan oleh kelompok usaha mikro kecil dan menengah (UMKM), KWT, kelompok tani, di masyarakat desa untuk dijual ke pasar atau masyarakat umum (perantara/broker). Hal itu sebagaimana diatur dalam Pasal 21 ayat (1) Permendesa 4/2015. Salah satu BUM Desa yang sukses dalam perdagangan dan jasa adalah BUM Desa Gentha Persada di Desa Tibubeneng, Kabupaten Badung, Bali. BUM Desa tersebut berhasil dalam menjalankan usaha simpan pinjam dan jasa pengelolaan sampah, pertunjukan barong, dan money changer sehingga mengantarkan sebagai BUM Desa terbaik di Kabupaten Badung, dengan manfaatnya dalam menyerap tenaga kerja (suryadewata.com, 2019).

3. Terkait

Peran sentral BUM Desa yakni terkait logistik Hal itu karena BUM Desa dapat melakukan kerja sama denga pihak ketiga untuk menjamin pemenuhan ketersediaan bahan baku, konsumsi rumah tangga masyarakat desa, maupun memenuhi pasar luar desa. Peran logistik tersebut dapat dijalankan oleh BUM Desa sebagaimana diatur dalam Pasal 25 Permendesa 4/2015.

4. Terkait Sektor Keuangan

BUM Desa dapat menjalankan jenis usaha keuangan (financial business) untuk pemenuhan modal maupun kebutuhan usaha mikro (kredit/pinjaman) yang dijalankan oleh pelaku usaha yang ada di desa. Hal itu sebagaimana diatur dalam Pasal 23 ayat (1) Permendesa 4/2015. Lebih lanjut, BUM Desa juga dapat berperan sebagai channeling bagi kelompok usaha di desa memperoleh kredit permodalan dari perbankan/lembaga keuangan yang lebih besar jumlahnya.

5. Terkait Korporasi

BUM Desa dapat melakukan kemitraan usaha dengan korporasi/perusahaan sesuai dengan usaha yang dijalankan oleh BUM Desa. Dengan cara tersebut. BUM Desa akan terlibat aktif dalam rantai produksi yang dijalankan oleh korporasi/perusahaan dan timbul timbal-balik keuntungan antara kedua belah pihak. Upaya tersebut dimungkinkan sebagaimana diatur dalam Pasal 25 huruf e Permendesa 4/2015.

Dengan peran sentral yang diberikan peraturan perundang-undangan tersebut, maka BUM Desa memiliki peranan penting bagi perekonomian desa. Perlu diketahui jumlah BUM Desa di Indonesia setiap tahun terus mengalami peningkatan, hal itu dapat dilihat pada grafik berikut (Katadata.co.id, 2018):

Dengan berkembangnya jumlah BUM Desa maka diharapkan hasil usahanya memberi pemasukan bagi Pendapatan Asli Desa (Pades) di banyak daerah. Kementerian Desa, PDT, dan Transmigrasi pada tahun 2017 mencatat terdapat lima BUM Desa yang behasil memproleh keuntungan dan omset yang tinggi serta memberdayakan masyarakat desa setempat, yakni BUM Desa Bangun Jaya, BUM Desa Karang Kandri Sejahtera, BUM Desa Mandala Giri Amerta, BUM Desa Tirtonirmolo, dan BUM Desa Tirta Mandiri (Katadata.co.id, 2018). BUM Desa 


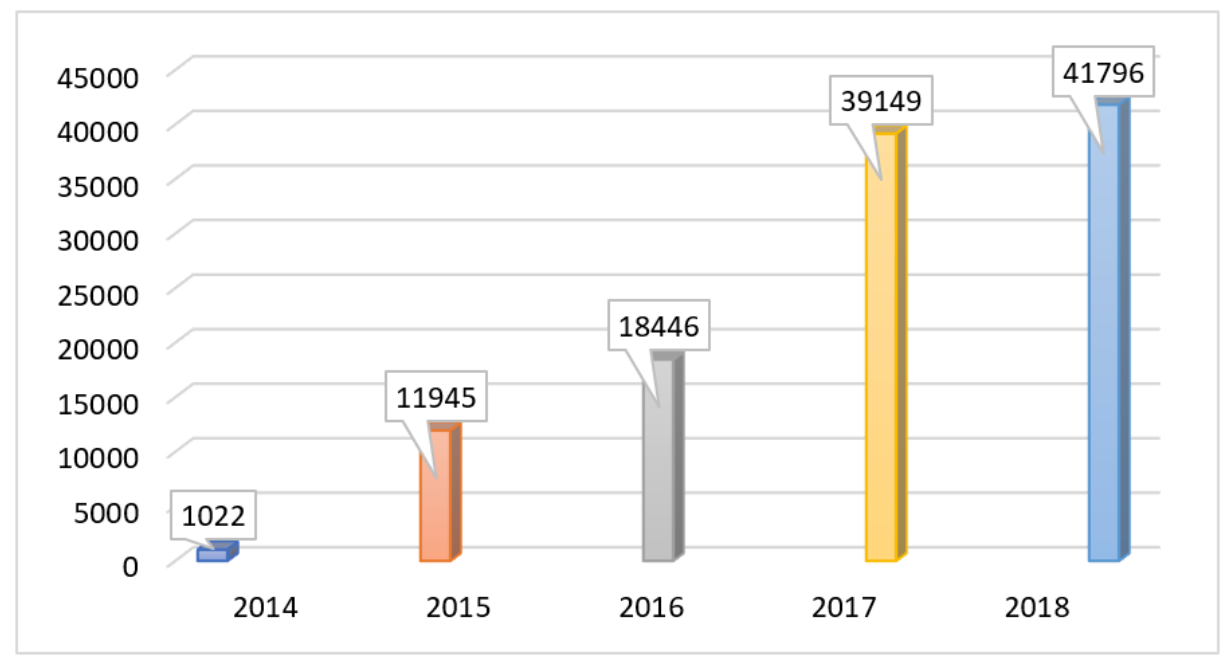

Gambar 2: Pertumbuhan Jumlah BUM Desa 2014-2018

Tirta Mandiri merupakan salah satu BUM Desa yang mencetak laba terbesar di Indonesia, yang per tahunmya mencapai Rp.2 miliar. Jenis usaha yang dijalankan BUM Desa di Desa Ponggok, Kecamatan/Kabupaten Klaten, Jawa Tengah tersebut, mulai dari mengelola destinasi wisata, kolam renang, perikanan, pembinaan PKL, penyediaan air bersih, jasa kontruksi hingga pengadaan barang dan jasa (Kementerian Desa, Pembangunan Daerah Tertinggal dan Transmigrasi Republik Indonesia [Kemendesa], 2016). Sedangkan pada 3 (tiga) BUM Desa lain tersebut menjalankan usaha simpan-pinjam. Sehingga melalui BUM Desa tersebut menyerap banyak tenaga kerja dan menggerakan aktivitas ekonomi masyarakat desa setempat.

\subsection{Upaya yang Dilakukan untuk Optimalisasi Pengembangan Ekonomi Perdesaan di Tengah Pandemi Covid-19}

\subsubsection{Mendorong BUM Desa Sebagai Penyedia Bahan Makanan Pokok di Pedesaan}

Covid-19 menimbulkan dampak negatif bagi penyediaan bahan makanan pokok di pedesaan, karena pembatasan keluar-masuk kendaraan atau orang yang mengangkut bahan pokok dari wilayah yang menetapkan PSBB. Hal itu menimbulkan penurunan permintaan hasil produksi pertanian perdesaan dari pasar, yang selanjutnya menimbulkan kerugian bagi petani serta menurunnya daya beli masyarakat desa. Oleh karena itu, perlu peran pemerintah dalam mengentaskan masalah penyediaan bahan makanan pokok di desa. Hal itu dilakukan dengan mendorong BUM Desa membentuk unit usaha produksi hasil pertanian, mela- 
lui kebijakan maupun insentif permodalan bagi BUM Desa. Dorongan tersebut juga dapat dilakukan terhadap masyarakat yang terkena PHK akibat Covid-19 maupun memiliki lahan pertanian, namun bukan tanaman bahan makanan pokok. Dengan dorongan tersebut, kemandirian desa dalam memenuhi kebutuhan pokoknya dari hasil pertaniannya sendiri dapat terwujud. Sehingga masalah pasokan yang tersendat, penurunan atau lonjakan harga yang naik drastis dapat diantisipasi dengan penyediaan bahan makanan pokok secara mandiri oleh BUM Desa.

\subsubsection{Peningkatan Kerjasama BUM Desa}

Seperti uraian sebelumnya, BUM Desa dapat berkerja sama mengembangkan usaha, baik dengan perusahaan, BUM Desa lain, perguruan tinggi, maupun pemerintah, sebagaimana dijamin dalam 25 huruf e Permendesa 4/2015. Terhadap perusahaan, maka BUM Desa dengan inisiatifnya dapat mengajukan proposal kerja sama penyediaan bahan baku produksi atau kemasan produk perusahaan. Hal itu seperti yang dilakukan oleh 30 BUM Desa di Kabupaten Buleleng, Bali yang berkerja sama dengan PT Pakar Cipta Karya dan PT Toya Ning Alami dalam produksi air mineral kemasan (Monitor.co.id, 2019). Kerja sama tersebut menguntungkan kedua belah pihak. Oleh karena itu, BUM Desa perlu didorong berkerja sama dengan perusahaan.

Kerja sama juga dilakukan dengan BUM Desa dari desa lain. Kolaborasi itu menghasilkan usaha dengan omzer dan jaringan pemasaran lebih luas Contohnya dilakukan BUM Desa Gianyar Aman yang berkolaborasi dengan 57 BUM Desa lain. Usaha yang dijalankan holding tersebut seperti perdagangan beras, gula, sembako, produk sejumlah perusahaan, dan komoditas pertanian petani Bali. Perusahaan holding tersebut terbukti mampu meningkatkan omset usaha seiring luasnya pemasaran, penyerapan hasil pertanian petani lokal Bali, dan penyerapan tenaga kerja lokal (Metrobali.com, 2020).

Selanjutnya kerja sama dapat dilakukan antara BUM Desa dengan perguruan tinggi, sehingga muncul inovasi produk terbaru, masukan bagi BUM Desa untuk mengembangkan usaha. Contohnya dilakukan oleh sejumlah BUM Desa di Sumatera Selatan dengan Universitas Sriwijaya, sehingga mahasiswa yang melakukan KKN, akan mendampingi, menata, dan meningkatkan mutu dan jenis produk/jasa usaha BUM Desa yang ada agar bisa diterima di pasaran (ekonomisumsel.com, 2016). Dengan kerja sama itu, tata kelola BUM Desa terus diperbaiki dan omsetnya terus meningkat.

Ketiga hal tersebut merupakan bentuk kerja sama yang dapat dilakukan BUM Desa dalam pengembangan usaha. Hal itu harus dilakukan terlebih pada masa Covid-19 yang telah menyebabkan banyak unit usaha yang mengalami penurunan permintaan, bahkan kebangkrutan. Oleh karena itu, kerjasama BUM Desa merupakan hal yang relevan dilakukan saat ini. 


\subsubsection{Pemberian Insentif atau Kredit Modal Kerja bagi BUM Desa}

Pemberian insentif atau kredit modal kerja bagi BUM Desa merupakan hal yang harus dilakukan saat ini. Hal itu terutama dengan keluarnya Peraturan Pemerintah No. 23 Tahun 2020 tentang Pelaksanaan Program Pemulihan Ekonomi Nasional dalam Rangka Mendukung Kebijakan Keuangan Negara untuk Penanganan Pandemi Corona Virus Disease 2019 (COVID-19) dan/atau Menghadapi Ancaman yang Membahayakan Perekonomian Nasional dan/atau Stabilitas Sistem Keuangan serta Penyelamatan Ekonomi Nasional. Dalam Peraturan tersebut diatur mengenai modal kerja tambahan bagi UMKM yang usahanya terdampak Covid-19. Dengan modal kerja tersebut, maka diharapkan untuk jangka pendek UMKM dapat memenuhi biaya operasional harian selama masa pandemi COVID 19. Adapun anggaran yang disiapkan untuk modal kerja tersebut mencapai Rp78 triliun (Katadata.co.id, 2018). Besaran modal kerja tersebut berbentuk kredit sebesar Rp5 juta hingga Rp10 juta dan langsung direstrukturisasi kredit modal kerja tersebut (Republika, 2020). Sehingga dengan modal kerja tambahan tersebut, diharapkan ekonomi UMKM dapat kembali pulih dari dampak Covid-19.

Akan tetapi, kredit tersebut hanya menyasar pada UMKM. Padahal terdapat jenis usaha lain yang terdampak Covid-19, seperti BUM Desa. Oleh karena itu, perlu dilakukan revisi atas PP No. 23 Tahun 2020 tersebut, dengan memasukkan BUM Desa sebagai salah satu penerima manfaat kredit modal kerja dari Pemerintah dalam penanganan Covid-19.

Lebih lanjut, dalam menangani dampak Covid-19, Pemerintah juga mencanangkan program restrukturisasi kredit dan subsidi bunga Pemerintah. Dalam hal restrukturisasi kredit, yang diatur dalam Peraturan Otoritas Jasa Keuangan Nomor 11/POJK.03/2020 Tentang Stimulus Perekonomian Nasional Kebijakan Countercyclical Dampak Penyebaran Coronavirus Disease 2019 mengatur cara restrukturisasi kredit, mulai dari penurunan suku bunga; perpanjangan jangka waktu; pengurangan tunggakan pokok; pengurangan tunggakan bunga; penambahan fasilitas kredit/pembiayaan; dan/atau konversi kredit/pembiayaan menjadi Penyertaan Modal Sementara. Dengan skema dan cara restrukturisasi tersebut, maka diharapkan beban kredit yang dihadapi pelaku usaha dapat lebih ringan, sehingga dapat fokus mencari upaya mempertahankan bisnis dan memperoleh keuntungan. Akan tetapi, seperti halnya program kredit modal kerja, sasaran program tersebut yakni UMKM, yang berbeda jenisnya dengan BUM Desa.

\subsubsection{Pendirian Pusat Pendidikan dan Pelatihan Pengelola BUM Desa}

Temuan penelitian Filya (2018) di Bojonegoro, Juliman \& Muslimin (2019), dan Laksono et al. (2016), menyatakan bahwa kurangnya kualitas dan kompetensi Sumber Daya Manusia (SDM) pengelola BUM Desa, menyebabkan kinerja BUM Desa tidak optimal. Oleh karena itu, perlu dilakukan peningkatan kualitas dan kompetensi SDM BUM Desa dalam menjalankan usaha BUM Desa. Salah satu hal yang dilakukan, yakni dengan mengadakan pelatihan dan pelatihan SDM pe- 
ngelola BUM Desa secara terpadu dan berkelanjutan. Dimana materi yang dapat disampaikan mulai dari metode pencatatan keuangan BUM Desa, pencatatan produksi, manajemen organisasi, mekanisme kerjasama antar lembaga/intansi, tata kelola sumber daya pegawai, pemasaran, dan lain sebagainya. Materi-materi tersebut tepat diisi oleh perusahaan-perusahaan yang jenis usahanya bergerak pada bidang yang sama, serta memiliki kompetensi keahlian sama juga dengan bidang ekonomi yang dikembangkan oleh BUM Desa. Hal itu seperti yang dilakukan oleh PT. Timah Tbk (TINS) dalam melatih BUM Des di Provinsi Kepulauan Bangka Belitung pada Oktober 2018. Selain memberikan sarana pelatihan dan modal, yang paling penting dalam pelatihan itu adalah pengelolaan manajemen dan keuangan BUM Desa supaya lebih baik pada masa mendatang (Medcom.id, 2018). Pelatihan oleh perusahaan kepada BUM Des tersebut termasuk dalam kategori Corpotate Social Responsibility (Bank BJB, 2020), yang diwajibkan oleh Pemerintah melalui berbagai peraturan, seperti dalam Undang-Undang No. 40 Tahun 2007 tentang Perseroan Terbatas serta Peraturan Pemerintah No. 47 Tahun 2012 tentang Tanggung Jawab Sosial dan Lingkungan Perseroan Terbatas. Dengan sinergitas tersebut, maka BUM Desa dapat menjalankan usahanya secara optimal, untuk memberikan kontribusi bagi masyarakat desa.

\section{Kesimpulan}

Berdasarkan uraian tersebut di atas, maka dapat disimpulkan dua hal. Pertama, urgensi optimalisasi peran BUM Desa dalam pengembangan ekonomi perdesaan di tengah pandemi Covid-19 karena beberapa hal, mulai dari potensi ekonomi pedesaan di Indonesia yang besar. Namun, adanya Covid-19 berdampak negatif terhadap kegiatan ekonomi masyarakat pedesaan. Oleh karena itu, solusi yang dilakukan adalah dengan optimalisasi peran BUM Desa yang ada di desa untuk memulihkan kondisi ekonomi masyarakat desa yang terdampak Covid19. Kedua, upaya yang dilakukan untuk optimalisasi peran BUM Desa dalam pengembangan ekonomi perdesaan di tengah pandemi Covid-19 diantaranya dengan mendorong BUM Desa sebagai penyedia bahan makanan pokok di desa; meningkatkan kerjasama BUM Desa dengan berbagai pihak untuk pengembangan usaha, mulai dari perusahaan, BUM Desa lain, maupun Perguruan Tinggi. Selanjutnya, perlu dilakukan pemberian insentif dan kredit modal kerja bagi BUM Desa yang terdampak Covid-19. Hal tersebut dilakukan dengan melakukan revisi terhadap PP No. 23 Tahun 2020 dan Peraturan OJK No. 11/POJK.03/2020, dengan menambahkan BUM Desa sebagai jenis usaha yang dapat memperoleh fasilitas perbankan untuk pemulihan ekonomi nasional, bukan hanya terbatas untuk UMKM. Selanjutnya, perlu didirikan pusat pendidikan dan pelatihan bagi SDM pengelola BUM Desa, khususnya dari perusahaan yang menyalurkan dana tanggung jawab dan sosial lingkungannya (Corporate Social Responsibility), untuk meningkatkan pengetahuan dan tata kelola BUM Desa dalam menjalankan usahanya. Dengan langkah tersebut, maka diharapkan BUM Desa dapat pulih dari dampak Covid-19 dan memberikan keuntungan bagi masyarakat desa. 


\section{Daftar Pustaka}

[1] Abdulgani, F., Aron, H., \& Prima, W. (2020). Pemetaan kondisi penghidupan: akses atas pangan dan kesehatan keluarga dalam masa pandemi COVID-19 di Jawa Barat. Bandung: LBH Bandung.

[2] antaranews.com. (2020, 22 Juni). Bappenas: Daya beli masyarakat hilang Rp362 triliun akibat COVID-19. Diakses 11 September 2020 dari https://www.antaranews.com/berita/1567452/ bappenas-daya-beli-masyarakat-hilang-rp362-triliun-akibat-covid-19.

[3] Basit, A. (2020). Dampak Covid-19 terhadap sektor pertanian. Jakarta: Biro Perencanaan Sekretariat Jenderal Kementerian Pertanian RI.

[4] Bank BJB. (2020, 23 Juli). Bank BJB latih BUMDes jadi konsultan pajak. Diakses 11 September 2020 dari https://www.bankbjb.co.id/tentang/ina/berita-dan-media/ berita/2020-07-23-093-bank-bjb-latih-bumdes-jadi-konsultan-pajak.

[5] beritasatu.com. (2020a, 27 April). Ketahanan pangan dan peran penting Bulog. Diakses 11 September 2020 dari https://www.beritasatu.com/nasional/625887/ ketahanan-pangan-dan-peran-penting-bulog.

[6] beritasatu.com. (2020b, 13 Mei). Jokowi sebut Covid-19 turunkan daya beli masyarakat. Diakses 11 September 2020 dari https://www.beritasatu.com/ekonomi/ 632171-jokowi-sebut-covid19-turunkan-daya-beli-masyarakat.

[7] BPS. (2018). Hasil pendataan Potensi Desa (Podes) 2018. Jakarta: Badan Pusat Statistik.

[8] BPS. (2019). Statistik Potensi Desa Indonesia 2018. Jakarta: Badan Pusat Statistik.

[9] BPS. (2020a). Hasil Survei Sosial Demografi Dampak COVID-19. Jakarta: Badan Pusat Statistik.

[10] BPS. (2020b). Perkembangan nilai tukar petani dan harga produsen gabah. Berita Resmi Statistik No. 36/05/Th. XXIII. Jakarta: Badan Pusat Statistik.

[11] PDPI. (2020). Pneumonia Covid-19: Diagnosis E penatalaksanaan di Indonesia. Perhimpunan Dokter Paru Indonesia. https://covid19.idionline.org/wp-content/uploads/ 2020/04/5.-Buku-PDPI-.pdf.

[12] Dewi, A. S. K. (2014). Peranan Badan Usaha Milik Desa (BUMDes) sebagai upaya dalam meningkatkan Pendapatan Asli Desa (PADes) serta menumbuhkan perekonomian desa. Journal of Rural and Development, 5(1), 1-14.

[13] ekonomisumsel.com. (2016, 11 Maret). Omzet BUMDes ada yang sampai 8.7 miliar. Diakses 11 September 2020 dari https://ekonomisumsel.com/ omzet-bum-desa-ada-yang-sampai-87-miliar.html.

[14] Elizabeth, R. (2007). Fenomena sosiologis metamorphosis petani: Ke arah keberpihakan pada masyarakat petani di pedesaan yang terpinggirkan terkait konsep ekonomi kerakyatan. Forum Penelitian Agro Ekonomi, 25(1), 29-42. doi: http://dx.doi.org/10.21082/fae.v25n1.2007.29-42.

[15] Filya, A. R. (2018). Optimalisasi pengelolaan Badan Usaha Milik Desa (BUMDes) dalam meningkatkan Pades di Kecamatan Bojonegoro Kabupaten Bojonegoro Provinsi Jawa Timur (Studi kasus di Desa Sukorejo Kecamatan Bojonegoro). Jurnal Ekonomi dan Keuangan Publik, 5(1), 19-39.

[16] Hidayat, R. (2020, 15 April). Nasib buram petani dan peternak di tengah pandemi COVID-19. tirto.id. Diakses 11 September 2020 dari https://tirto.id/ nasib-buram-petani-dan-peternak-di-tengah-pandemi-covid-19-eNpo.

[17] Ibrahim, J. (2007). Teori dan metodologi penelitian hukum normatif. Malang: Bayumedia Publishing. 
[18] Izzati, R. A. (2018, 19 November). Cek Fakta: Apakah benar kemiskinan di desa menurun dua kali lipat dibanding di kota?. theconversation.com. Diakses 11 September 2020 dari https://theconversation.com/ cek-fakta-apakah-benar-kemiskinan-di-desa-menurun-dua-kali-lipat-dibanding-dikota-106524.

[19] Jamaludin, A. N. (2015). Sosiologi perdesaan. Bandung: CV Pustaka Setia.

[20] Juliman \& Muslimin, A. (2019). Optimalisasi tatakelola Badan Usaha Milik Desa. Jurnal Penelitian Pendidikan Sosial Humaniora, 4(1), 471-483. doi: https://doi.org/10.32696/jp2sh.v4i1.271.

[21] Junaidi, M. A. (2018). Peran Badan Usaha Milik Desa (BUMDes) dalam penguatan ekonomi masyarakat di Desa Kedung Turi Kecamatan Taman Kabupaten Sidoarjo (Skripsi, Universitas Airlangga).

[22] Katadata.co.id. (2018, 5 Desember). BUMDes meningkatkan pendapatan asli desa. Diakses 11 September 2020 dari https:/ / katadata.co.id/arsip/infografik/5e9a558d9c084/ bumdes-meningkatkan-pendapatan-asli-desa.

[23] Kemendesa. (2016, 31 Agustus). BUMDes Tirta Mandiri cetak laba bersih 2 m/tahun. Kementerian Desa, Pembangunan Daerah Tertinggal dan Transmigrasi Republik Indonesia. Diakses 11 September 2020 dari https://kemendesa.go.id/berita/view / detil/1866/BUMDesa-tirta-mandiri-cetak-laba-bersih-2-mtahun.

[24] Kementerian Pertanian. (2018). Statistik Pertanian 2018. Diakses 11 September 2020 dari http://epublikasi.setjen.pertanian.go.id/arsip-perstatistikan/160-statistik/ statistik-pertanian/586-statistik-pertanian-2020.

[25] Kompas.com. (2020a, 6 April). Cegah penularan Covid-19, ini 4 kelompok masyarakat yang perlu isolasi diri. Diakses 11 September 2020 dari https://nasional.kompas.com/read/2020/04/06/10511821/ cegah-penularan-Covid-19-ini-4-kelompok-masyarakat-yang-perlu-isolasi-diri.

[26] Kompas.com. (2020b, 3 Juli). CSIS: Inflasi rendah karena daya beli masyarakat menurun. Diakses 11 September 2020 dari https:/ / money.kompas.com/read/2020/07/03/ $164000826 /$ csis--inflasi-rendah-karena-daya-beli-masyarakat-menurun.

[27] Koran Jakarta. (2017, 9 Oktober). Abaikan pertanian dan industri, kualitas pertumbuhan merosot: Kinerja ekonomi I pertumbuhan sektor pertanian dan industri terus tersendat. Diakses 11 September 2020 dari http://www.koran-jakarta.com/ abaikan-pertanian-dan-industri--kualitas-pertumbuhan-merosot/.

[28] Laksono, I., Salim, A., \& Utomo, S. D. (2016). Mempertegas pengaturan penetapan desa adat. Policy brief: Seri mengawal implementasi undang-undang desa. Pusat Telaah dan Informasi Regional (PATTIRO). Diakses 11 September 2020 dari http:/ / pattiro. org $/$ ?wpdmact $=$ process\&did=MTY0LmhvdGxpbms=

[29] liputan6.com. (2019, 3 April). Kontribusi desa ke ekonomi nasional bisa capai $r p 19.912$ triliun dalam 7 tahun. Diakses 11 September 2020 dari https://www.liputan6.com/bisnis/read/3932426/ kontribusi-desa-ke-ekonomi-nasional-bisa-capai-rp-19912-triliun-dalam-7-tahun.

[30] Marzuki, P. M. (2011). Penelitian hukum. Jakarta: Kencana Prenada Media Group.

[31] Medcom.id. (2018, 21 Oktober). PT Timah Latih Bumdes Babel Kembangkan Usaha. Diakses 11 September 2020 dari https://www.medcom.id/ekonomi/mikro/ VNxqBwDb-pt-timah-latih-bumdes-babel-kembangkan-usaha.

[32] Media Indonesia. (2020, 1 Mei). Nasib buruh tani kian merana di tengah pandemi Covid-19. Diakses 11 September 2020 dari https://mediaindonesia.com/read/detail/ 309291-nasib-buruh-tani-kian-merana-di-tengah-pandemi-covid-19. 
[33] Metrobali.com. (2020, 23 Juli). Holding BUMDes Gianyar lebarkan sayap ke seluruh Bali. Diakses 11 September 2020 dari https://metrobali.com/ holding-bumdes-gianyar-lebarkan-sayap-ke-seluruh-bali/.

[34] Nuryanti, S., \& Swastika, D. K. S. (2011). Peran kelompok tani dalam penerapan teknologi pertanian. Forum Penelitian Agro Ekonomi, 29(2), 115-128. doi: http://dx.doi.org/10.21082/fae.v29n2.2011.115-128.

[35] Puspayanthi, N. L. P. A. D., Wahyuni, M. A., \& Prayudi, M. A. (2017). Penguatan pengelolaan keuangan desa dan optimalisasi peran BUMDes untuk kemandirian desa pada desa di Kabupaten Jembrana. JIMAT (Jurnal Ilmiah Mahasiswa Akuntansi) Undiksha, 8(2). doi: http:/ /dx.doi.org/10.23887/jimat.v8i2.13258.

[36] Sevilla, C. G., Ochave, J. A., Punsalan, T. G., Regala, B. P., Uriarte, G. G., \& Tuwu, A. (1993). Pengantar metode penelitian. UI Press.

[37] suarabanyuurip.com. (2020, 12 Januari). BUMDes ring 1 gas JTB sukses budidaya ayam petelor, sehari raup omset $R p 3,2$ juta. Diakses 11 September 2020 dari https://www.suarabanyuurip.com/kabar/baca/ bumdes-ring-1-gas-jtb-sukses-budidaya-ayam-petelor-sehari-raup-omset-rp3-2-juta.

[38] Monitor.co.id. (2019, 21 Agustus). 30 BUMDes di Buleleng teken kerjasama pengolahan air minum dengan perusahaan swasta. Diakses 11 September 2020 dari https://monitor.co.id/2019/08/21/ 30-bumdes-di-buleleng-teken-kerjasama-pengolahan-air-minum-denganperusahaan-swasta/.

[39] suryadewata.com. (2019). BUMDES Gentha Persada terbaik diantara 46 BUMDES di Badung. Diakses 11 September 2020 dari http://suryadewata.com/2019/04/01/ bumdes-gentha-persada-terbaik-diantara-46-bumdes-di-badung/.

[40] tribunnews.com. (2020, 20 Mei). Mendes: Jumlah ODP Corona di desa lebih tinggi daripada di kota. Diakses 11 September 2020 dari https: / / www.tribunnews.com/corona/ 2020/05/20/mendes-jumlah-odp-corona-di-desa-lebih-tinggi-daripada-di-kota.

[41] voaindonesia.com. (2020, 3 April). Jabar ungkap dua kasus COVID-19 karena mudik. Diakses 11 September 2020 dari https://www.voaindonesia.com/a/ jabar-ungkap-dua-kasus-covid-19-karena-mudik-/5358503.html.

[42] Wibisono, A. F., \& Panuntun, B. (2020). Optimalisasi fungsi BUMDes melalui inovasi dan manajemen organisasi sebagai upaya meningkatkan kemandirian desa. JAMALI - Jurnal Abdimas Madani dan Lestari, 2(1), 1-9. 